Effects of the Mount St. Helens Eruption on the Benthic Fauna of the Toutle River, Muddy River, and Pine Creek Drainage Basins, Washington 


\section{METRIC CONVERSION FACTORS}

Multiply

foot (ft)

cubic yard $\left(\mathrm{yd}^{3}\right)$

mile (mi)

square mile $\left(\mathrm{mi}^{2}\right)$

cubic foot per second $\left(\mathrm{ft}^{3} / \mathrm{sec}\right)$
By

0.3048

0.7646

1.609

2.590

.02832
To obtain

meter $(\mathrm{m})$

cubic meter $\left(\mathrm{m}^{3}\right)$

kilometer $(\mathrm{km})$

square kilometer $\left(\mathrm{km}^{2}\right)$

Cubic meter per serond $\left(\mathrm{m}^{3} / \mathrm{s}\right)$

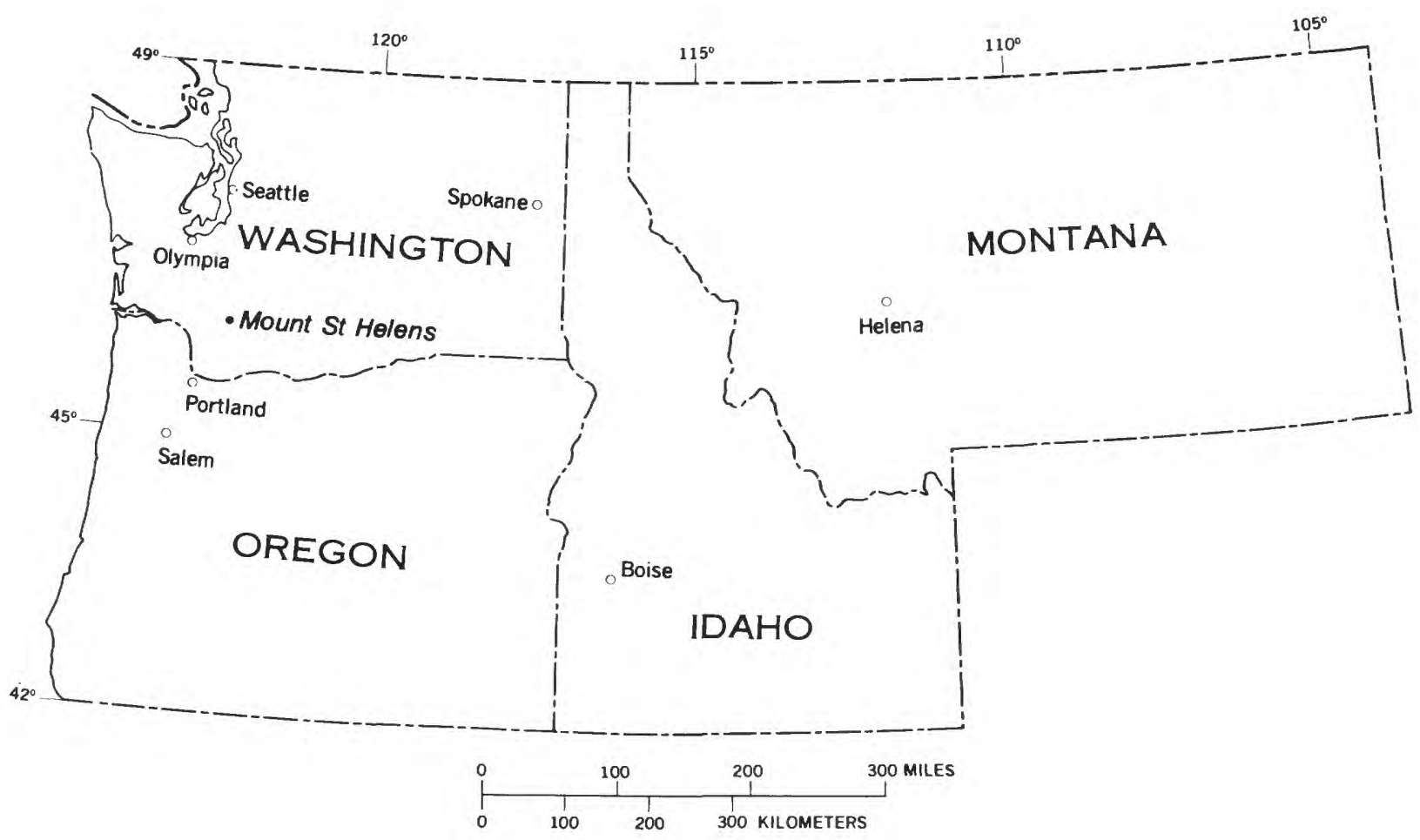

COVER: North Fork Toutle River, June 30, 1980. Volcanic mud flow breccia and debris from the May 18, 1980 eruption of Mount St. Helens (in upper right) are as much as several hundred feet thick in the reach shown. Photograph by Austin Post, U.S. Geological Survey. 
Effects of the Mount St. Helens Eruption on the Benthic Fauna of the Toutle River, Muddy River, and Pine Creek Drainage Basins, Washington

By Luis A. Fuste'

Hydrologic Effects of the Eruptions

of Mount St. Helens, Washington, 1980

GEOLOGICAL SURVEY CIRCULAR 850-H 
United States Department of the Interior

JAMES G. WATT, Secretary

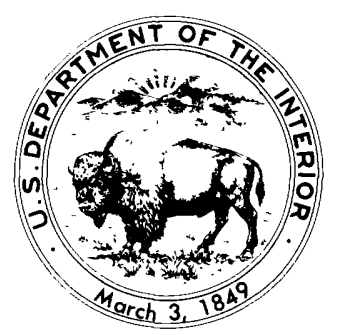

\section{Geological Survey}

Doyle G. Frederick, Acting Director

Library of Congress catalog-card No. 81-600042 


\section{FOREWORD}

On May 18, 1980, after more than a month of earthquakes and eruptions, Mount St. Helens, in southwestern Washington, exploded in a volcanic eruption more violent than any in the conterminous United States during the 20th century. A lateral blast of hot gas and rock particles devastated an area of about 150 square miles on the northern side of the mountain knocking down trees to a distance of 15 miles. Several minutes later, a giant ash cloud rose to about 60,000 feet. Winds then carried the ash cloud across the United States, with heavy fallout and deposition in eastern Washington and parts of Idaho and Montana. Earlier, smaller eruptions deposited ash in western Washington and parts of Oregon and Canada.

The hydrologic effects of the May 18 eruption have been both widespread and intense. During the eruption, a massive debris avalanche moved down the north flank of the volcano depositing about 3 billion cubic yards of rock, ice, and other materials in the upper 17 miles of the North Folk Toutle River valley. The debris deposits are about 600 feet thick in the upper reaches of the valley. Following the avalanche, runoff from the melted glaciers and snow, and possible outflow from Spirit Lake, caused an extraordinary mudflow in the North Fork Toutle River. The mudflow shattered and uprooted thousands of trees, destroyed most of the local bridges, and deposited an estimated 25,000 acre-feet of sediment in the Cowlitz River channel. A considerable amount of additional sediment was conveyed through the lower Cowlitz into the Columbia River where it was deposited and formed a shoal that blocked the shipping channel. Mudflows also occurred in the South Fork Toutle River and in tributaries on the east flank of Mount St. Helens which enter Swift Reservoir.

As part of a concerted Geological Survey effort to study the volcanic event and to identify potential hazards, Survey hydrologists have mounted an intensive program to document the hydrologic effects of the eruptions. The major initial hydrologic findings are reported in this circular series. Quick, useful assessment was made possible only because the Survey has long conducted extensive water-resources investigations in the affected areas of Washington, Oregon, and Idaho. Hence, there was a well-defined basis for identification and documentation of the types and magnitudes of hydrologic changes.

The Geological Survey Circular 850, "Hydrologic Effects of the Eruptions of Mount St. Helens, Washington, 1980," consists of individually published short chapters that emphasize data collection activities, field observations, and initial comparisons of preand post-eruption conditions. The series will cover hydrologic events occurring on May 18 in the Toutle and Cowlitz River; physical alteration of the Toutle River system; the chemical and physical quality of precipitation, streams, and lakes affected by volcanic ash fall; ash-leaching studies; and Mount St. Helens glaciers.

Doyle G. Frederick

Acting Director 



\section{CONTENTS}

Page

$\mathrm{H} 1$

Abstract

Introduction - - - -

Description of study areas

Methods-_-_-_._-

Results and discussion
Results and discussion-Continued

Pre-eruption -

Post-eruption-1-0.- 9

Miscellaneous sites - 11

Summary -

References cited

\section{ILLUSTRATIONS}

FIGURE 1. Map showing sampling locations on the North and South Forks Toutle River and selected tributaries, and on selected lakes in the vicinity of Mount St. Helens

2. Map showing sampling sites on the Muddy River and Pine Creek drainage basins

3. Photograph of Castle Creek, showing the damage caused by the mudflow_

\section{TABLES}

TABLE 1. Taxa and numbers of benthic invertebrates at sampling sites near Mount St. Helens, Wash., March 28-30, 1980

2. Relative abundance of benthic invertebrate populations before and after the eruption of May 18, 1980

3. Stream classification based on functional attributes of benthos samples, March 28-30, 1980

4. Taxa and numbers of benthic invertebrates at sites near Mount St. Helens, Wash., July 27-29, 1980

5. Stream benthos from miscellaneous sampling sites near Mount St. Helens, Wash 

HYDROLOGIC EFFECTS OF THE ERUPTIONS OF

MOUNT ST. HELENS, WASHINGTON, 1980

\title{
EFFECTS OF THE MOUNT ST. HELENS ERUPTION ON THE BENTHIC FAUNA OF THE TOUTLE RIVER, MUDDY RIVER, AND PINE CREEK DRAINAGE BASINS, WASHINGTON
}

\author{
By LuIS A. FusT'E
}

\begin{abstract}
Benthic invertebrate samples were collected in the Toutle River, Muddy River, and Pine Creek drainage basins on March 28-30,1980, to document pre-eruption conditions in watersheds surrounding Mount St. Helens, in the event of a major eruption. A highly diverse fauna was present at all sampling sites. Mayfly and midge (chironomid) larvae were the most numerous organisms. The mayflies were most common in the third-order streams, and the chironomid larvae were most common in firstand second-order streams. An attempt was made to classify the streams studied according to the functional role of organisms in the processing of organic matter. It was hypothesized that many of the organisms exhibiting multiple functional roles in processing of organic matter were predominantly detritivores. This classification was then compared to a conceptual stream ecosystem model.

The volcanic eruption of May 18 destroyed most, if not all, of the benthic fauna present at the sites sampled. The cataclysmic events that took place during the explosion modified the topography to the point of eliminating some of the watersheds, while in others the riparian vegetation was scoured out, along with the natural substrate of the streams. Of the remaining sites, a very simplified community was found in July, composed primarily of midges and blackfly larvae (98-100 percent of the total number of organisms collected).

The potential for recolonization of stream benthos appears to be relatively high because of the creation of new habitats near backwaters and pools from springs that were exposed by the scouring action of the mudflows. These environments are very stable and provide ideal conditions for algal growth and for chironomid larvae to thrive.
\end{abstract}

It is believed that these "seed habitats," in conjunction with downstream drift from unaffected tributaries and aerial oviposition by winged adults of aquatic insects, will be the principal sources of stream benthos for the affected streams in the coming years. However, successful recolonization will be dependent mainly on substratum and channel stability, with some improvement of the chemical quality of the stream water.

Several lakes and Coldwater Creek, north of the volcano, as well as some lakes formed on top of the mudflow that went down the North Fork Toutle River valley, were visited in July to document survival of stream and lake benthos and to determine whether the new lakes had indications of colonization by stream benthos. Of the lakes visited, Spirit Lake, Lake St. Helens, and Tradedollar Lake, the latter had the greatest variety of lake benthos. Mosquito larvae (Culex sp.) were the only organisms found in Spirit Lake. Coldwater Creek contained rat-tailed maggots (Tubifera sp. (?)) in areas of decaying organic matter. Numerous chironomids (midges) and blackfly larvae were found on some of the lakes on the mudflow area.

\section{INTRODUCTION}

On March 28-30, 1980, stream benthos (bottomdwelling organisms) and water-quality characteristics were sampled along the main stem and various tributaries of the North and South Forks of the Toutle River, Muddy River, and Pine Creek. These samples were taken to document preeruption conditions in watersheds surrounding 
Mount St. Helens, Wash., in the event of a major eruption.

Three days after the first signs of volcanic activity (March 27, 1980), volcanic ash had been dispersed onto the northeast, east, and southeast flanks of the mountain, on the vegetation and snow-covered areas. As a result of the major eruption on May 18 and the cataclysmic events that occurred following the eruption, such as pyroclastic flows, ash fallout, and mudflows, the benthic fauna in most of the streams draining from Mount St. Helens were decimated or destroyed.

The purpose of this report is to present and discuss the biological data collected on March 28-30 and compare them with similar information obtained on July 27-29, after the major eruption.
The water-quality data collected are presented in another report in this circular series.

\section{DESCRIPTION OF STUDY AREAS}

Samples of stream benthos were collected from five locations on the main stem of the North and South Forks Toutle River and from seven streams on the northwest and southeast sides of Mount St. Helens (figs. 1 and 2). Prior to the eruptions, all the sampling stations had gravel-armored streambeds with fairly stable banks. The stream gradient of the sampling sites ranged from low gradient (stations $1,2,6,11,12$, and 13) and medium gradient (stations $4,7,9$, and 10) to a very steep gradient (stations 3, 5, and 8). Low gradient streams are

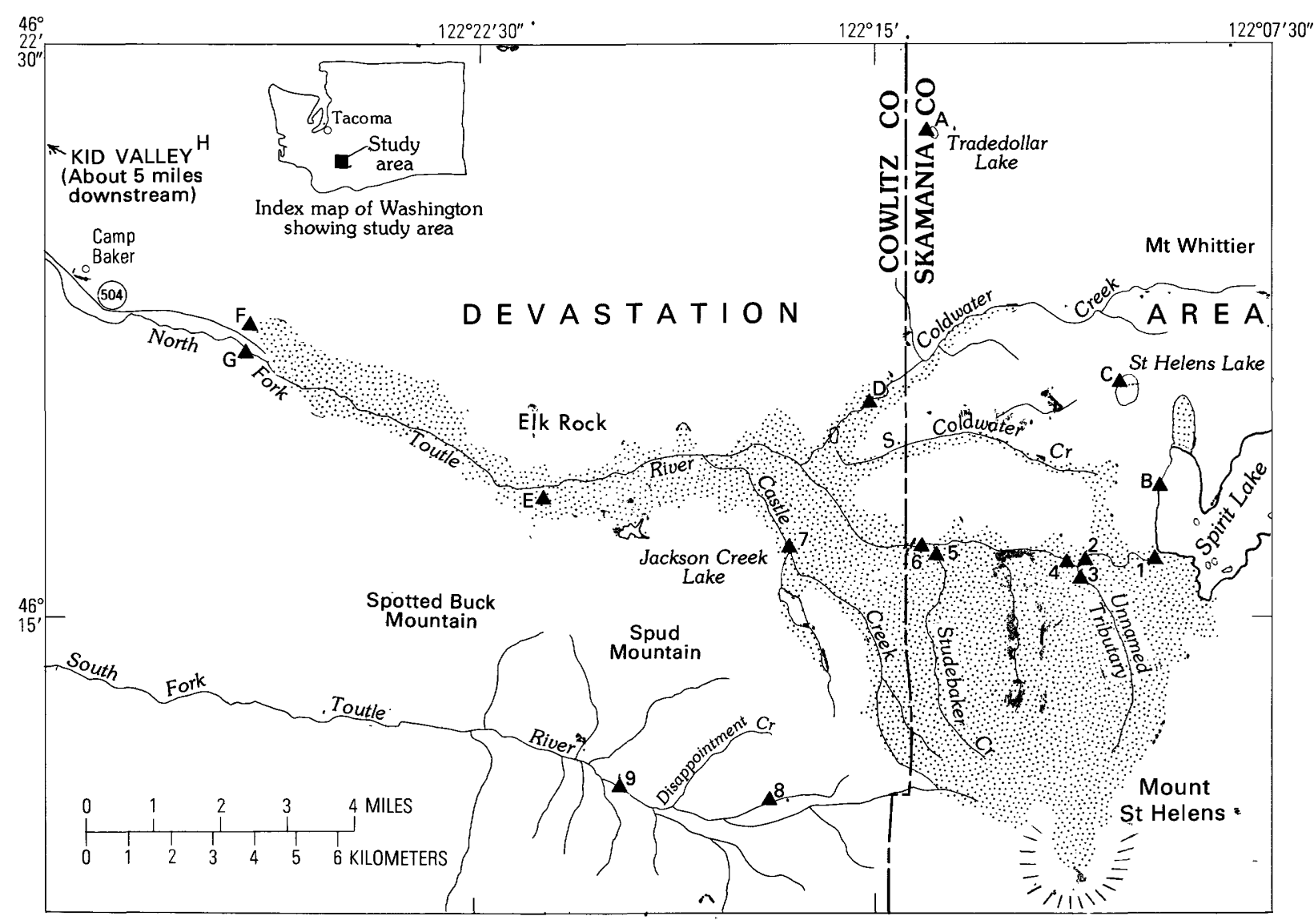

FIGURE 1.-Locations of sampling sites on the North and South Forks Toutle River and selected tributaries, and on selected lakes in the vicinity of Mount St. Helens. Stream locations shown are those that existed prior to the May 18, 1980, eruption. 


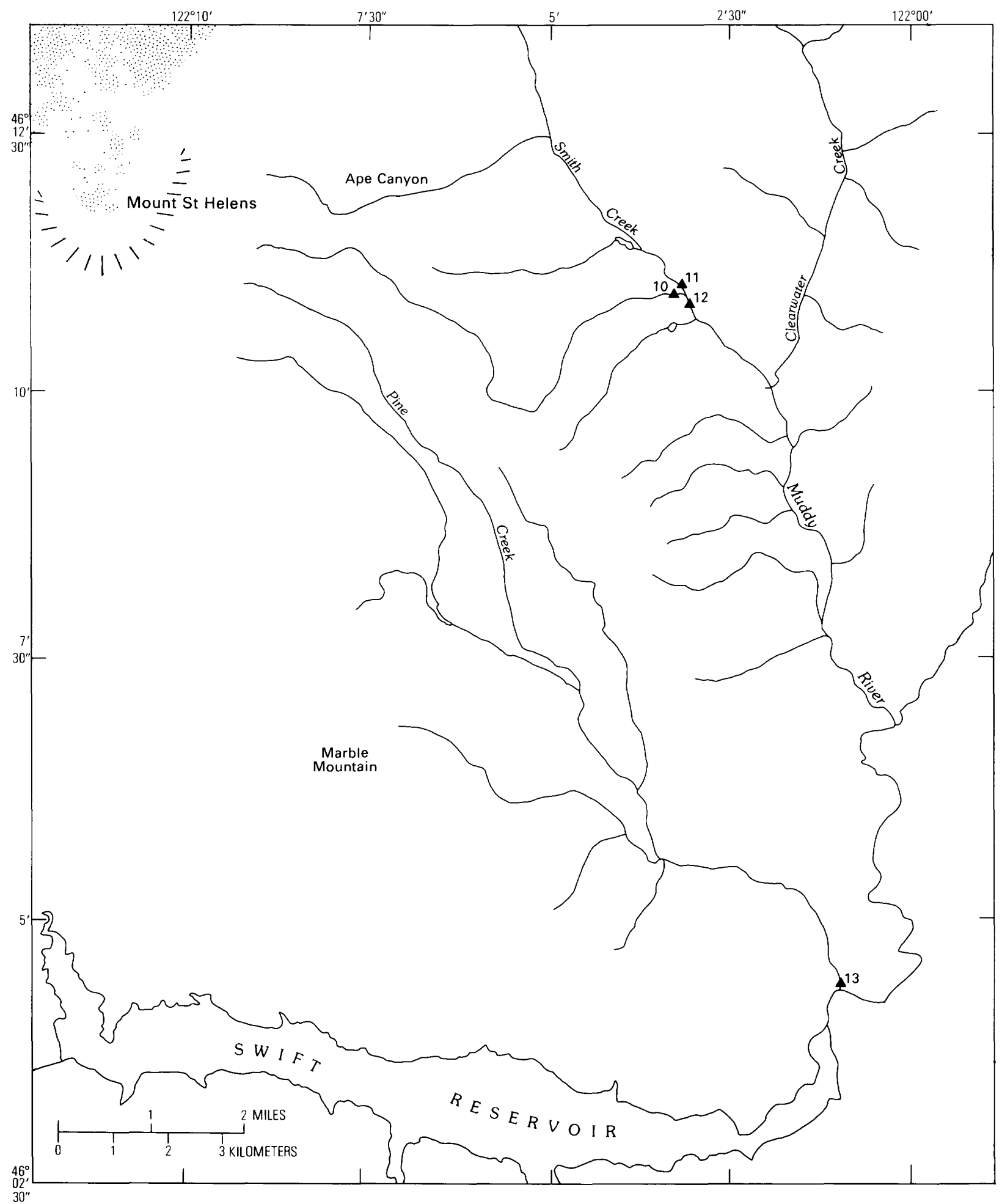

FIgURE 2.-Location of sampling sites on the Muddy River and Pine Creek drainage basins. Stream locations shown are those that existed prior to the May 18, 1980, eruption.

defined here as those within a range of $0.014 \mathrm{ft} / \mathrm{ft}$ to $0.24 \mathrm{ft} / \mathrm{ft}$. Medium gradients are those with a slope between $0.038 \mathrm{ft} / \mathrm{ft}$ and $0.049 \mathrm{ft} / \mathrm{ft}$, and steep gradients are those with a slope between 0.067 $\mathrm{ft} / \mathrm{ft}$ and $0.075 \mathrm{ft} / \mathrm{ft}$. With the exception of the South Fork Toutle River and Pine Creek, the ripar- 
ian (riverbank) vegetation was a dense coniferous forest. The South Fork Toutle River had a sparse riparian vegetation because of extensive logging operations over the past 10 years. Pine Creek had mainly deciduous vegetation along the streambanks in the sampled reach. The unnamed tributary of the North Fork Toutle (station 3) and Studebaker Creek (station 5) had the greatest canopy covers of all sampling sites.

Many of the tributaries of the North Fork Toutle River provided several miles of good spawning gravel for chinook, chum, and coho salmon (State of Washington, Department of Fisheries, 1973). The South Fork Toutle River valley is narrow, and the tributaries have steep gradients that generally limited upstream migration of adult salmon from the main stem of the South Fork.

All the sampling stations from which benthic invertebrate samples were collected were on first (stations 2, 3, and 10), second (stations 4, 5, and 7), or third order (stations 6,9,11,12, and 13) streams (Strahler, 1957). The stream order was determined by using $1: 62,500$ scale maps.

As a result of the major and subsequent eruptions, all the sampling sites visited in March received mudflows, pyroclastic flows, ash falls, or a combination of these. The North Fork Toutle River downstream from Spirit Lake was plugged by a mudflow which obliterated stations 1-7 (fig. 1). Part of the hot mudflow went down the Castle Creek drainage basin, uprooting and felling trees and thus creating an impoundment close to its original confluence with the North Fork Toutle River. The entire basin was stripped of all vegetation (fig. 3). Similar mudflows occurred in Pine Creek, Smith Creek, and the Muddy River drainage basins (fig. 2).

A mudflow on the South Fork Toutle River destroyed sampling sites 8 and 9 (fig. 1). The river's main stem was divided into two channels, one having turbid water resulting from a large amount of suspended sediment being transported downstream and the other having virtually no suspended sediment.

A reconnaissance visit was made on July 28 to the main stem of the North Fork Toutle River near Kid Valley and to Coldwater Creek (fig. 1). The North Fork carried a heavy load of sediment from natural sources and sediment brought into suspension by dredging operations. In the Coldwater Creek valley, two lakes near the confluence with the North Fork Toutle River were formed by mudflow impoundment. Farther upstream, an impoundment similar to the one at Castle Creek was created from piles of trees stripped from the drainage basin by the force of the volcanic blast and washed down into the channel.

\section{METHODS}

With the exception of stations 1,8 , and 9, replicate samples of benthic invertebrates were collected with a Surber sampler $(0.210-\mathrm{mm}$ mesh openings) at every sampling station. Each pair of replicate samples was then combined, preserved with 70-percent ethanol, and brought to the U.S. Geological Survey laboratory in Tacoma, Wash., for processing, sorting, and identification. Synoptic or reconnaissance samples were collected from stations 1, 8, and 9. For these samples, benthic organisms were collected either with a dip net or by examining all the types of habitat present (wood, leaves, pools, riffles, etc.) and sampling randomly from each. The majority of the organisms in the samples were identified to the genus level and, in many cases, to the species level when adult specimens were collected from the snowbanks next to the streams.

\section{RESULTS AND DISCUSSION PRE-ERUPTION}

A total of 87 taxonomic groups (taxa) were identified from all sampling stations (table 1). The most abundant organisms were two genera of mayfly, Baetis and Iron, and chironomid (midge) larvae. Nearly all the sampling sites had a rich faunal community when sampled in March. Biological samples collected at stations 1,8 , and 9 were considered to be nonrepresentative for comparative purposes because they were only reconnaissance samples. Station 7, Castle Creek, had the richest faunal assemblage, with a total of 53 taxa. Station 3, the unnamed tributary of the North Fork Toutle River, had the least fauna, with 12 taxa.

Mayflies were dominant (greater than 50 percent) in the third-order streams (stations $6,11,12$, and 13), and the chironomid larvae (table 2) were dominant (greater than 46 percent) in the firstand second-order streams (stations 2, 3, 4, 5, and 10). The only exception was Castle Creek (station 7 ), a second-order stream in which mayflies were dominant ( 62 percent).

The streams visited may be classified (Vannote and others, 1980) on the basis of the functional role benthic invertebrates have in processing organic 


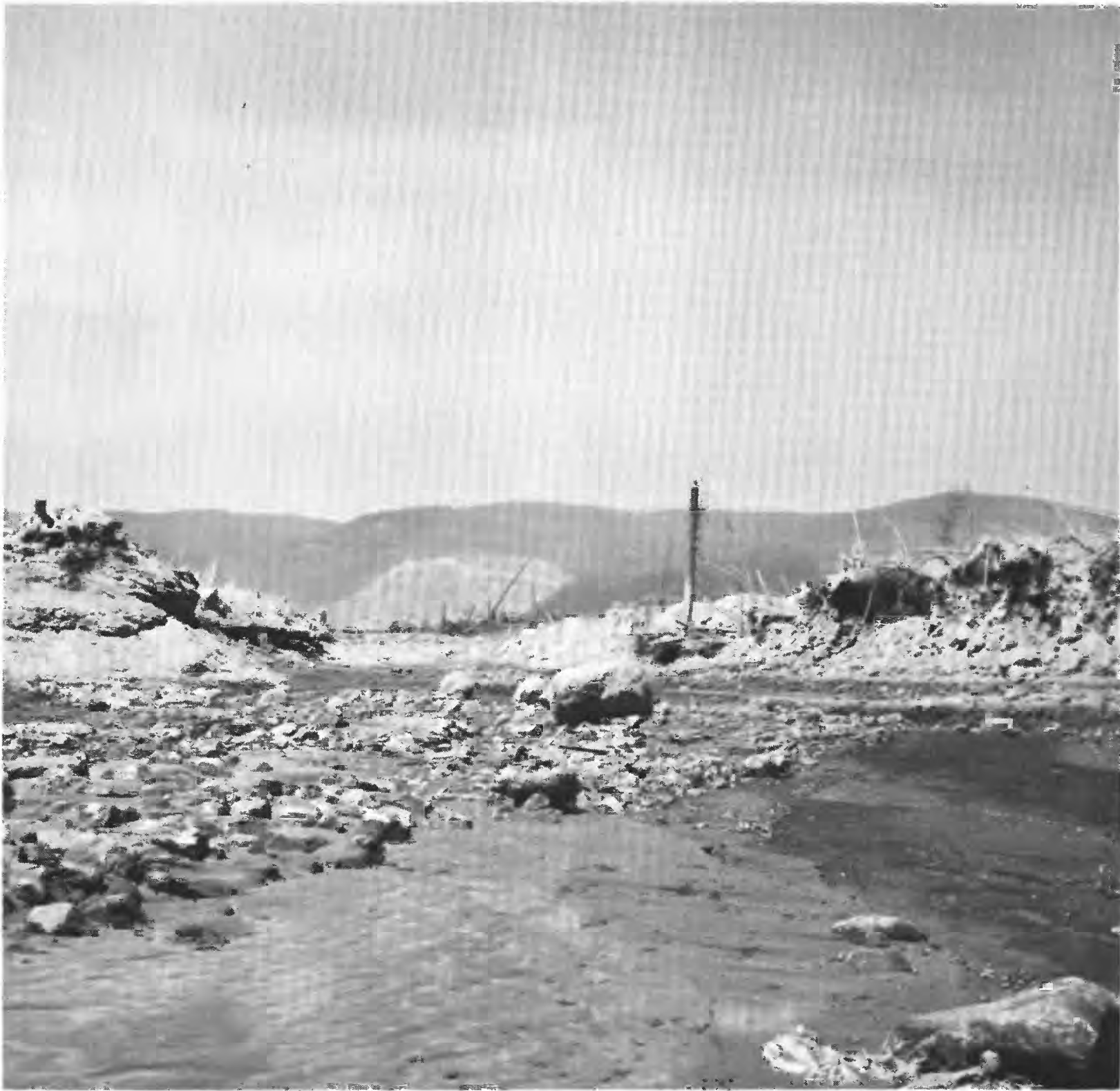

FiguRE 3.-Castle Creek, showing the damage caused by the mudflow.

matter (table 3) from terrestrial and instream sources. Theoretically, stream ecosystems follow a transition from headwaters to higher stream orders in the utilization of organic matter to sustain the benthic invertebrate communities. Headwaters are typically more dependent upon terrestrial inputs of particulate organic matter, especially coarse particles (CPOM) such as leaf litter, with little or no photosynthetic production of organic matter in the stream. CPOM-feeding invertebrates, or shredders, and detritivores feeding on fine particulate organic matter (FPOM, gener- ally less than $1 \mathrm{~mm}$ in diameter), or collectors, are the dominant macroconsumers. In the higher order streams there is more dependency upon organic production by photosynthesizing algae and aquatic plants, along with input of FPOM from upstream. This conceptual idea of stream ecosystems is imperfect, because factors such as channel shape, watershed slope, discharge, terrestrial input characteristics, and the light and thermal regimes of the streams introduce variations into the model (Cummins, 1975). In spite of these watershed influences, this continuum concept 
TABLE 1.-Taxa and numbers of benthic invertebrates at sampling sites near Mount St. Helens, Wash., March 28-30, 1980

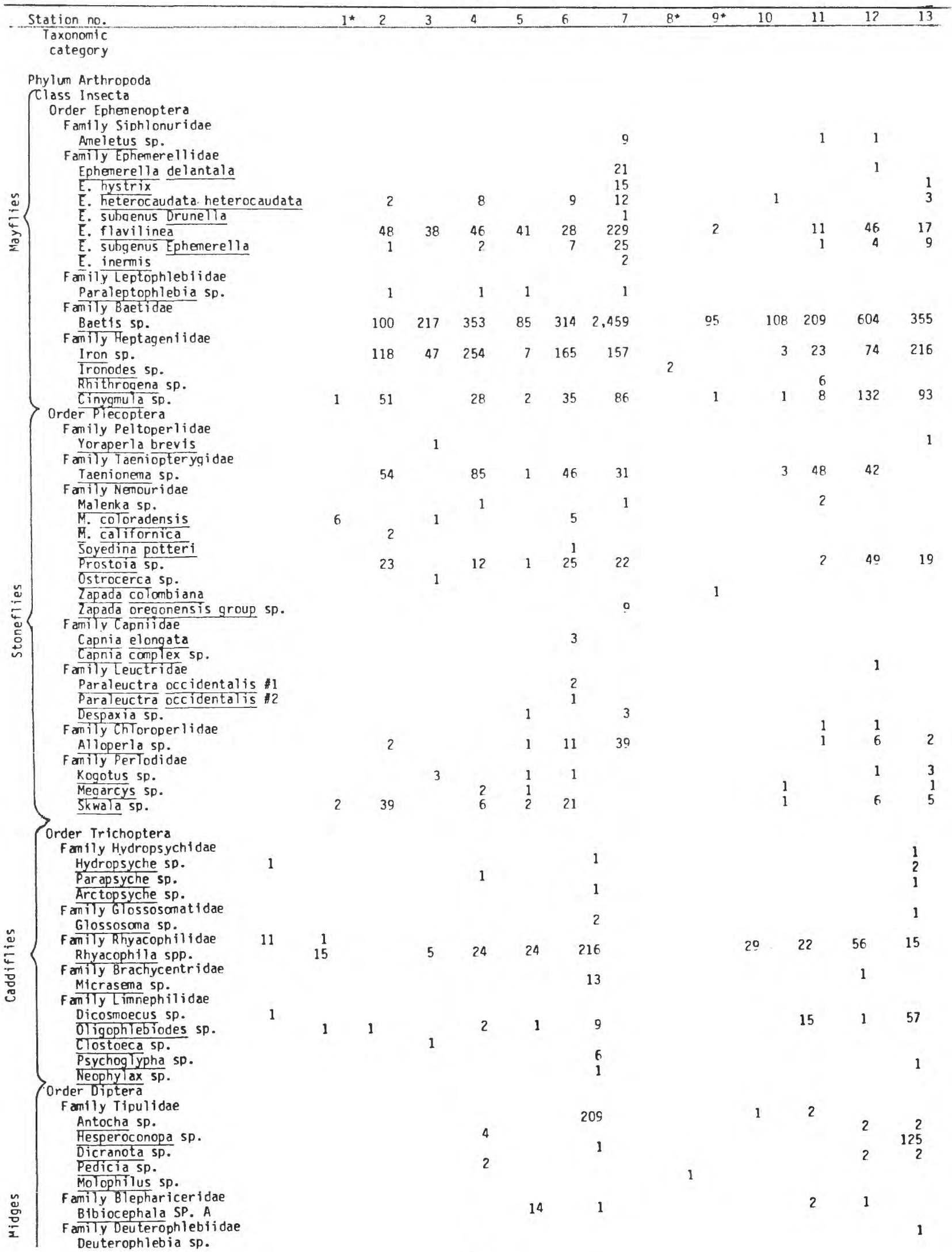


TABLE 1.-Taxa and numbers of benthic invertebrates at sampling sites near Mount St. Helens, Wash., March 28-30, 1980-Continued

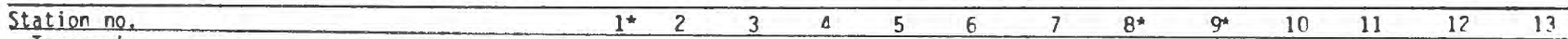

$$
\begin{aligned}
& \text { Taxonomic } \\
& \text { category }
\end{aligned}
$$

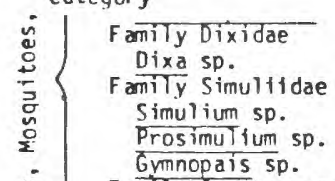

Family Ceratopononidae

Fanily Chironomidae
Family Psychodidae

Maruina SP.

Family Taban idae

Fanily Empididae

Clinocera $5 p$.

Chetifera sp.

Hemerodromia sp.

Beetles

$\left\{\begin{array}{l}\text { Order Coleoptera } \\ \text { Family Elmidae }\end{array}\right.$ order Collembola

Springtails

Family Hypoqastruridae

Fanlly Entomobrydae

(Family $\operatorname{Sininthruridae}$

$\begin{array}{rrr}67 \quad 20 & 1,228 \\ 1 & 5 & 45\end{array}$

$\begin{array}{lllll}23 & 391 & 505 & 578 & 161\end{array}$

$\begin{array}{rr}3 & 1 \\ 5 & 42 \\ & 2 \\ 295 & 1 \\ & 1.037\end{array}$

1

$\begin{array}{lll}1 & 3 & 4 \\ & 1 & 1\end{array}$

289

3

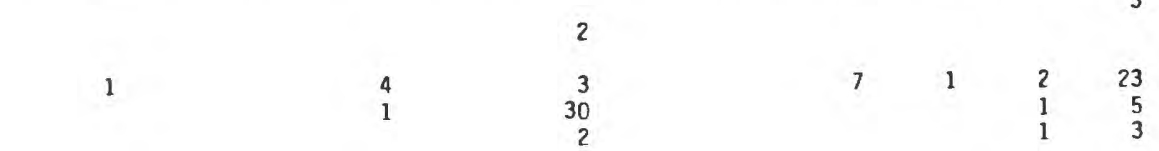

110 $\begin{array}{cl}\text { Scuds } & \begin{array}{l}\text { Class Crustacea } \\ \text { Order Amphipoda } \\ \text { Fam } 11 \text { y Gamaridae }\end{array}\end{array}$

Seed Shrimp Order Ostracoda

Order Copepoda

$\begin{array}{ll} & \text { Suborder Cyclopolda } \\ \text { Water } & \text { Suborder Harpacticoida }\end{array}$

Fleas Class Arachnoidea

Subclass Arachnida

Order Acarina*

Family Hydraphantidae

Subfanily Protzínae

Protzia subgenus Calonyx sp.

Fanily Torrenticolidae

Subfamily Torrenticolinae

Torrenticola sp.

Subfamily Testudinac ar inae

Testudacarus sp.

Family Lebertidae

Lebertia sp.

Family Sperchontiidae

Subfamily Sperchonti inae

Sperchon Sp.

Family Momoni idae

Styoomomonia subgenus Allomomonia sp.

Family Hygrobatidae

Atractides sp.

Flatworms Phylum platyheminthes

Class Turbellaria

Order Tricladida

nquatic Phylum Annelida

Earth- Class Clitellata

worms $\}$ Subclass 0ligochaeta

worms Phylum Mollusca

Snails $\left\{\begin{array}{c}\text { Class Gastropoda } \\ \text { Family Pleuroceridae } \\ \text { Goniobasis sp. }\end{array}\right.$

Family Planorbiidae sp. 1

sp. $\# 2$

Round- Phylum Nenatoda

worms

$\begin{array}{llllllll}1 & 1 & 2 & 2 & 2 & 1 & 1 & 2 \\ 1 & & 2 & 1 & 1 & 2 & \end{array}$

1

6

1

3

1

5

21

4

4

1

3

121

$\begin{array}{llll}2 & 11 & 9 & 104\end{array}$

1
2

]

\begin{tabular}{|c|c|c|c|c|c|c|c|c|c|c|c|c|c|c|}
\hline Total & number 0 & taxa & $\begin{array}{r}9 \\
118\end{array}$ & $\begin{array}{r}26 \\
862\end{array}$ & $\begin{array}{r}12 \\
820\end{array}$ & $\begin{array}{r}23 \\
2,666\end{array}$ & $\begin{array}{r}25 \\
380\end{array}$ & $\begin{array}{r}20 \\
996\end{array}$ & $\begin{array}{r}53 \\
4,890\end{array}$ & $\begin{array}{l}1 \\
2\end{array}$ & $\begin{array}{r}8 \\
2,420\end{array}$ & $\begin{array}{r}21 \\
795\end{array}$ & $\begin{array}{r}25 \\
5 n 0\end{array}$ & $\begin{array}{rr}26 & 35 \\
1,414 & 1.358\end{array}$ \\
\hline
\end{tabular}

21

82

1

Explanation:

* Samples collected at stations 1, 8, and 9 are synoptic surveys and by nn means intended to be used as representative samples.

* Susan Hahn, written commun., 1980. U.S. Genloqical Surver, WRD, Menlo Park CA 
PRE-ERUPTION (March 28-30, 1980)

$\begin{array}{lllllllllll}\text { STATION NO. } & 2 & 3 & 4 & 5 & 6 & 7 & 10 & 11 & 12 & 13\end{array}$ ORDER

$\begin{array}{lllllllllll}\text { EPHEMENOPTERA } & 37.2 & 36.8 & 25.7 & 37.4 & 56.0 & 61.7 & 14.2 & 50.9 & 61.0 & 51.1\end{array}$ $\begin{array}{lllllllllll}\text { PLECOPTERA } & 13.7 & .4 & 4.0 & .3 & 8.6 & 2.6 & .6 & 10.2 & 7.6 & 2.3\end{array}$ $\begin{array}{lllllllllll}\text { TRICHOPTERA } & 2.0 & .1 & .2 & .7 & 2.6 & 5.1 & .6 & 4.3 & 4.1 & 5.7\end{array}$ $\begin{array}{lllllllllll}\text { DIPTERA } & 45.6 & 62.2 & 69.5 & 47.3 & 31.4 & 27.2 & 76.9 & 32.6 & 26.0 & 33.3\end{array}$ $\begin{array}{lllllllllll}\text { ACARI } & .1 & -- & -- & -- & -- & .8 & .2 & .6 & 1.0 & 1.3\end{array}$ $\begin{array}{lllllllllll}\text { Others } & 1.3 & .5 & .7 & .5 & .1 & .3 & .1 & 1.4 & .3 & 6.3\end{array}$

POST-ERUPTION (July 27-29, 1980)

$\begin{array}{lllllllllll}\text { STATION NO. } & 2 & 3 & 4 & 5 & 6 & 7 & 10 & 11 & 12 & 13\end{array}$ ORDER

EPHEMENOPTERA

PLECOPTERA

TRICHOPTERA

DIPTERA

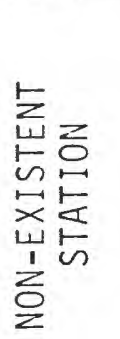

ACARI

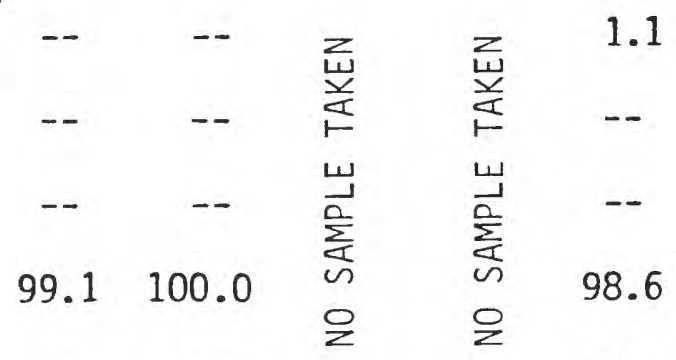

Others 
TABLE 3.-Stream classification based on functional attributes ${ }^{*}$ of benthos samples, March 28-30, 1980

\begin{tabular}{|c|c|c|c|c|c|c|c|c|c|c|}
\hline STATION NO. & 2 & 3 & 4 & 5 & 6 & 7 & 10 & 11 & 12 & 13 \\
\hline $\begin{array}{l}\text { TROPHIC } \\
\text { CATEGORY }\end{array}$ & & & & & & & & & & \\
\hline $\begin{array}{l}\text { Shredders } \\
\text { Scrapers } \\
\text { Engulfers } \\
\text { Piercers } \\
\text { Collectors } \\
\text { Generalists** } \\
\text { Carnivorous } \\
\text { parasitic }\end{array}$ & $\begin{array}{r}2.7 \\
6.4 \\
4.3 \\
-- \\
3.8 \\
82.8\end{array}$ & $\begin{array}{r}0.1 \\
-- \\
-- \\
-- \\
1.0 \\
98.8\end{array}$ & $\begin{array}{r}0.5 \\
3.2 \\
.3 \\
-- \\
48.4 \\
47.9\end{array}$ & $\begin{array}{r}0.6 \\
.6 \\
4.1 \\
-1 \\
6.0 \\
88.6\end{array}$ & $\begin{array}{r}2.5 \\
6.0 \\
.4 \\
-- \\
3.0 \\
88.1\end{array}$ & $\begin{array}{r}0.7 \\
.8 \\
1.2 \\
.04 \\
8.6 \\
88.0\end{array}$ & $\begin{array}{r}0.5 \\
1.1 \\
-- \\
1.3 \\
96.4\end{array}$ & $\begin{array}{r}0.6 \\
9.4 \\
.2 \\
-- \\
2.6 \\
86.2\end{array}$ & $\begin{array}{r}3.6 \\
3.1 \\
.9 \\
-- \\
.3 \\
90.5\end{array}$ & $\begin{array}{r}1.4 \\
.2 \\
10.4 \\
-.- \\
6.8 \\
79.9\end{array}$ \\
\hline
\end{tabular}

1. $\star$ Merritt and Cummins, 1978

2. ** "Generalists" are those organisms having multiple functions in the stream benthos by being processors of organic matter drifting from upstream sources, consuming attached algae, having predatory behavior, or a combination of these depending on the amount of canopy cover and availability of upstream food sources.

(Vannote and others, 1980) is useful in understanding the biological processes taking place in flowing water.

The sampling sites around Mount St. Helens would represent, with some limitations, the headwaters of this conceptual model. On the basis of the available literature summarized by Merritt and Cummins (1978) and the taxonomic level of identification used in this study, many of the benthic invertebrates found appear to exhibit multiple functional roles in the benthic community as shredders, engulfers, scrapers, collectors, or piercers. This role will be dependent on food availability, stream habitat conditions, and the season of the year. One can hypothesize that these "generalists" (table 3) are composed predominantly of detritivores feeding on fine particulate organic matter resulting from CPOM-feeding invertebrates in the fall and winter seasons. According to this stream ecosystem model, shredders play an important role in processing the CPOM. Sampling took place during the spring snowmelt and very little leaf fall was present in the streams, suggesting that most, if not all, of the leaf fall was degraded into fine particulate organic matter in the fall when these shredders were probably more abundant.

Other than suspended sediment introduced into the streams from old logging operations on the South Fork Toutle River, there was no evidence, based on the biological data collected, of any maninduced effects on any of the other sampling sites prior to the May 18 eruption.

\section{POST-ERUPTION}

Nineteen taxa were identified from the four sites remaining after the eruption of May 18 (table 4). The benthic fauna at stations $7,9,10$, and 13 shows a simplified community structure composed predominantly of blackflies and chironomids (midge larvae; table 2). It was impossible to obtain samples from stations 11 and 12 because of the excessive amount of fine suspended sediment. The stream channel at station 9 in the South Fork Toutle River was divided into two channels. One of the channels carried virtually no sediment in suspension, while the other carried a high suspendedsediment load. The decrease in abundance of organisms at the remaining sites may be due in part to a seasonal change in numbers and kinds of or- 
ganisms, as well as to the effects of the blast such as modifications of the streambed substrate and alteration of the stream water quality. The survival of several forms of midge larvae (some genera from the subfamily Diamesinae) in the Castle Creek drainage basin despite the high temperatures from the mudflow is unusual, because they are known to be particularly sensitive to increases in temperature (W. Coffman, Dept. of Biology, University of Pittsburgh, oral commun.,
1980). These larvae are apparently characteristic of streams and did not come from nearby Spirit Lake. How they survived is presently unknown.

The mudflows and pyroclastic flows left the headwaters devoid of living vegetation. Any algae or mosses growing on the rocks were also scoured away. The absence of tree canopy may have modified the thermal regime of the water, although the higher temperatures found in July were normal for that time of the year (Collings and Hill, 1973).

TABLE 4.-Taxa and numbers of benthic invertebrates at sites near Mount St. Helens, Wash., July 27-29, 1980

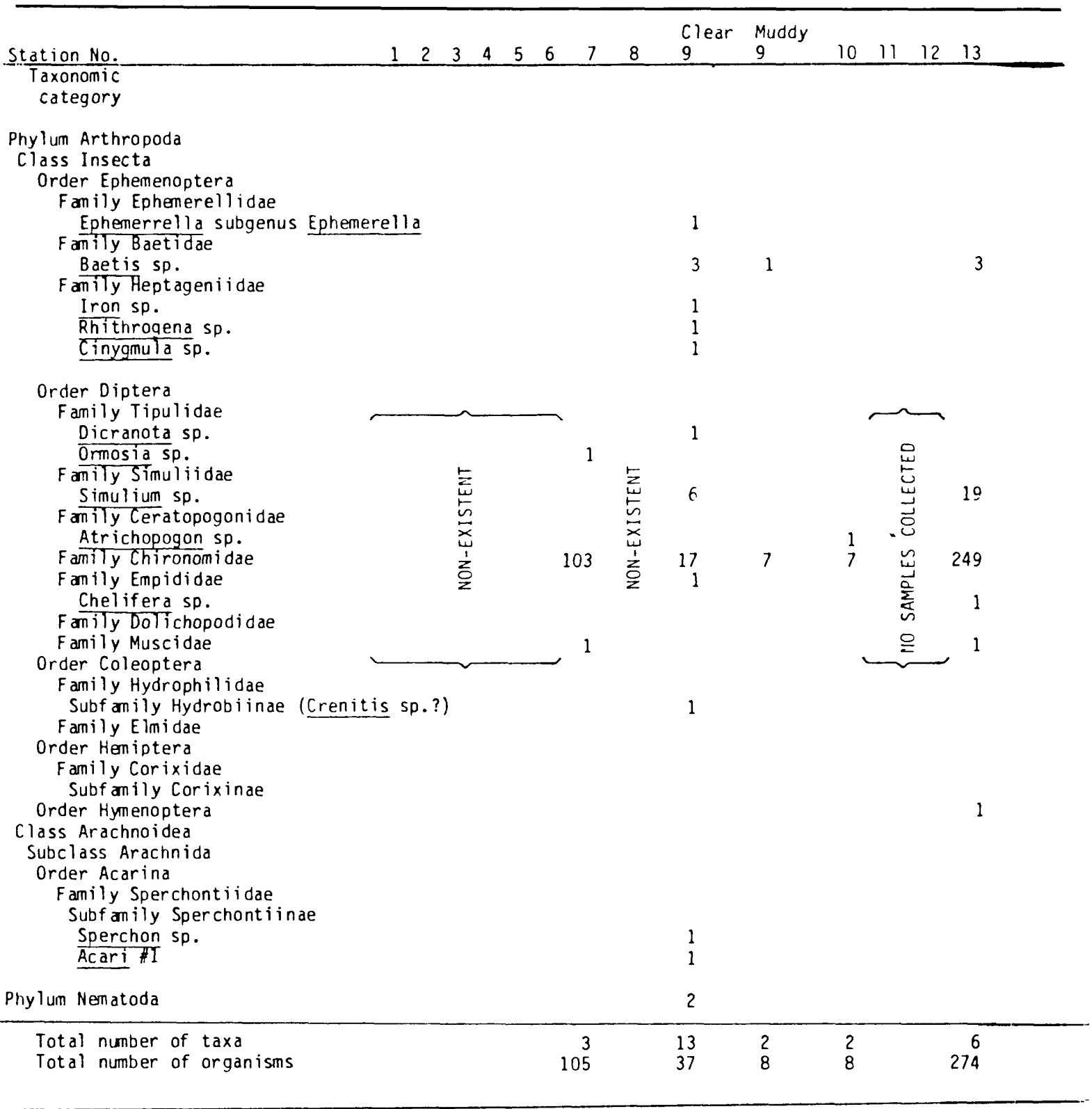


Before the eruption, there was a normal succession of pools and riffles at sample sites. After the cataclysmic event, riffles predominated, with a high suspended-sediment concentration (more than 3,000 milligrams per liter) and considerable bed material being transported downstream (average thickness of 3-9 inches in the Muddy River in July), making the stream-bottom substrate extremely unstable for a person to stand in the middle of the stream. These conditions created an unsuitable environment for the survival of stream benthos, owing to the scouring action of the sediment. The excessive turbidities prevented algae from growing on rocks; thus, instream food sources were absent also. As of July, there were no mechanical means of holding back the suspended sediment. It will probably take years for the affected streambeds to reach equilibrium again. It is also highly probable that removing trees that have fallen across the riverbeds may affect the natural process.

The most significant changes in the streamwater chemistry, following the eruption of May 18, were sharp increases in total constituents (predominantly the suspended fraction) of sulfate, chloride, aluminum, manganese, boron, and iron when compared with the stream-water chemistry in March, 37 days before the major eruption (Klein, U.S. Geological Survey, oral commun., 1980).

The potential for recolonization of stream benthos appears to be relatively high because of the creation of new habitats near backwaters and pools from springs. Many of these springs were obscured by vegetation and topsoil, prior to the eruption of May 18. The scouring action of the mudflows exposed the source of many of the springs. These provide a stable environment for algal growth and bottom-dwelling organisms. Such "seed habitats" will probably be one of the major sources of stream benthos for the affected streams in the coming years. Therefore, successful recolonization of the stream benthos will depend principally on substratum stability followed by improvement of the chemical quality of the stream water.

\section{MISCELLANEOUS SITES}

A reconnaissance survey of benthic invertebrates was made at several miscellaneous sites on June 6 and July 27-29, 1980 (table 5). The sites included: (1) Tradedollar Lake, Spirit Lake, and Lake St. Helens; (2) Coldwater Creek; (3) one of the newly formed ponds near Elk Rock Lake; (4) the two new channels of the North Fork Toutle River below the mud dam; and (5) the main stem of the North Fork Toutle River at Kid Valley.

All three lakes were within the blast area of the volcanic explosion; thus, most of the surrounding vegetation was killed. Logs from some larger trees remain in the drainage basins of the lakes. The presence of skunk cabbage and various fern species was evidence that new growth was occurring. Of the three lakes, Tradedollar Lake had the greatest variety of benthos. Spirit Lake and Lake St. Helens showed no evidence of zooplankton. Mosquito larvae (Culex sp.) were the only organisms found in Spirit Lake. Samples from Coldwater Creek were collected above the lowest wooddebris-mud impoundment. Rat-tailed maggots (Tubifera sp. (?)), generally found in areas with decaying organic matter, were the only benthic invertebrates collected at this site.

One of the newly formed lakes on top of the mud dam on the North Fork Toutle River was sampled for indications of colonization by stream benthos. Numerous chironomid (midge) and blackfly larvae were found.

The mudflow that went down the North Fork Toutle River and stopped a few miles upstream from Camp Baker, a logging camp, divided the main stem of the river into two channels, on the north and south sides of the mud dam. The benthic fauna found in the two channels was somewhat similar, in that at least 50 percent of the taxa were common to both. The north channel, containing clear water, appeared to originate from the southerly flowing tributaries. The south channel is further subdivided upstream into a clear side and a muddy side. Samples were collected from the "clear" channels, since the muddy water did not allow sampling with a Surber sampler. Synoptic sampling in the muddy channel did not yield any organisms. The muddy side received water from the main channel of the North Fork Toutle River, seeping from underneath the mud dam, whereas the clear south channel received water from Castle and Jackson Creek Lakes.

Although no numerical estimates are available, the fauna in the North Fork Toutle River near Kid Valley retained a higher degree of structural complexity than the other sites sampled in the posteruption surveys. Because of the presence of mature nymph stoneflies (Calineuria californica and Pteronarcys princeps), whose large bodies could 
TABLE 5.-Stream benthos from miscellaneous sampling sites near Mount St. Helens, Wash. (+=present)

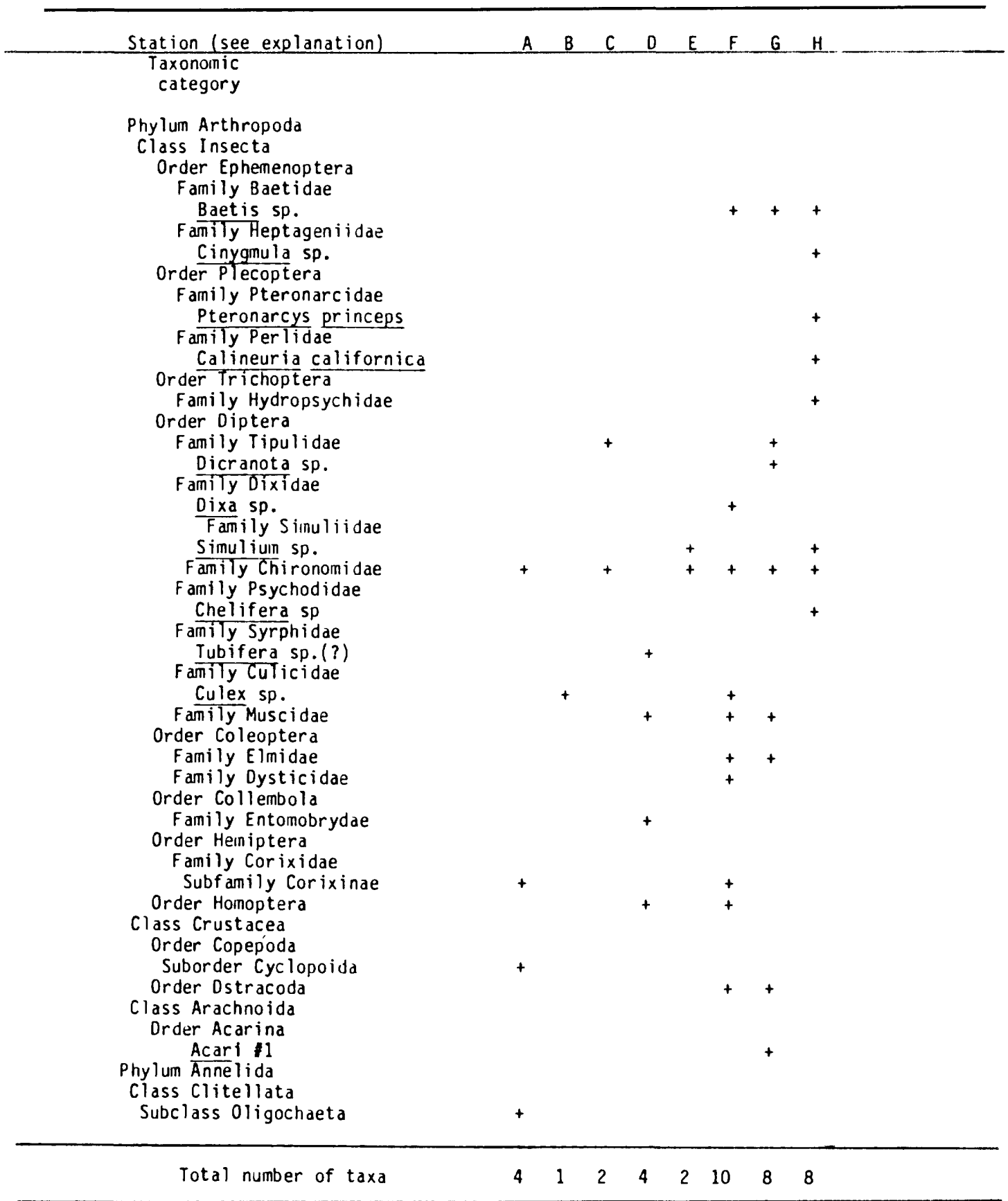

Explanation:

A. Tradedollar Lake $-7 / 28 / 80$

B. Spirit Lake - $7 / 28 / 80$

C. Lake St. Helens - 7/28/80

D. Coldwater $\mathrm{Cr}$. above lowest inpoundinent - 7/28/80

E. Debris pile (red pond) next to Elk Rock Lake - 7/30/80

F. North Fork Toutle River below mud dam (right side) $-7 / 30 / 80$

G. North Fork Toutle River below mud dam (left side) $-7 / 30 / 80$

H. North Fork Toutle River near Kid Valley $-6 / 6 / 80$ and $7 / 30 / 80$

(Cinygmula sp. and Calineuria californica were collected on $6 / 6 / 80$ ) 
easily have been crushed by the exceedingly high bedload transported downstream, it is most likely that these organisms drifted downstream from tributaries outside the blast zone. This is supported by the fact that Pteronarcys normally takes 3 to 4 years to reach the adult stage. The presence of the other organisms at the downstream stations is probably due to a combination of downstream drift and aerial oviposition (egg laying) by adult forms. Adults of aquatic insects were conspicuous at all sites visited in July.

It will be essential to assess the degree to which stream channel stability will be affected by increasing streamflow and tree salvage operations.

\section{SUMMARY}

A highly diverse benthic fauna was present at the sampling sites visited during March 27-29, 1980. Mayflies (Baetis sp. and Iron sp.) and chironomid (midge) larvae were the most numerous organisms. In general, mayfly nymphs were most common in the third-order streams, and the chironomid larvae were most common in the firstand second-order streams. If the streams are classified on the basis of the role bottom-dwelling organisms have in processing organic matter, the benthic community found in March was composed of organisms exhibiting multiple functional roles as shredders, scrapers, engulfers, collectors, or piercers. According to the continuum concept, the benthic fauna in these first, second, and thirdorder streams are, in theory, composed of detritivores, which are the dominant macroconsumers. It is possible to speculate that the majority of these "generalists" are detritivores, since most of the leaf fall from the previous autumn had already disappeared and probably was being utilized as fine particulate organic matter. If these streams had been sampled in the fall, one might expect a higher percentage of shredders in the benthic community, since coarse particulate organic matter (leaves, twigs, and other material) would be more readily available.

The volcanic eruption of May 18, 1980, destroyed most, if not all, of the benthic fauna at the sites sampled. After the eruption, a much simplified benthic community was found, composed principally of blackflies and chironomid larvae. The mudflows and pyroclastic flows scoured out the vegetation along with the natural substrate of the streams, virtually eliminating all allochthonous and autochthonous sources of organic matter and destroying the diverse habitats found prior to May 18.

Observations at miscellaneous sites after the May 18 eruption indicated that, of the three lakes visited (Spirit Lake, Lake St. Helens, and Tradedollar Lake), Tradedollar Lake had the greatest variety of lake benthos. A rat-tailed maggot, Tubifera sp., characteristic of environments with decaying organic matter, was found in Coldwater Creek.

A slightly higher level of structural complexity was observed in the benthic fauna farther downstream than in the upstream sites in the North Fork Toutle River. This was attributed mainly to downstream drift from the tributaries outside the blast zone.

The potential for recolonization of stream benthos appears to be relatively high because of the creation of new habitats near backwaters and pools from springs. Spring environments are generally stable and provide ideal conditions for algal growth and for chironomid larvae to thrive. These "seed habitats," downstream drift from unaffected tributaries, and winged adults of aquatic insects from other areas laying eggs on the water will be the principal sources of stream benthos for the affected streams in the coming years. Nevertheless, successful recolonization will be dependent mainly on substratum stability and further improvement of the chemical quality of the stream water.

\section{REFERENCES CITED}

Collings, M. R., and Hill, G. W., 1973, The hydrology of ten streams in western Washington as related to several $\mathrm{Pa}$ cific salmon species: State of Washington Department of Fisheries Water-Resources Investigations 11-73, 149 p.

Cummins, K. W., 1975, The ecology of running waters: theory and practice: in Proceedings of the Sandusky River Basin Symposium, May 2-3, 1975, Tiffin, Ohio, p. 277-293.

Merritt, R. W., and Cummins, K. W., 1978, An introduction to the aquatic insects of North America: Dubuque, Iowa, Kendall/Hunt Pub. Co., 441 p.

State of Washington, Department of Fisheries, 1973, Fisheries resources in southwest Washington: southwest Washington river basins study: Review Draft, Olympia, Washington, $154 \mathrm{p}$.

Strahler, A. N., 1957, Quantitative analysis of watershed geomorphology: American Geophysical Union Transactions, v. 38 , p. $913-920$.

Vannote, R. L., Minshall, G. W., Cummins, K. W., Sedell, J. R., and Cushing, C. E., 1980, The river continuum concept: Canadian Journal of Fisheries and Aquatic Sciences, v. 37, p. 130-137. 
